
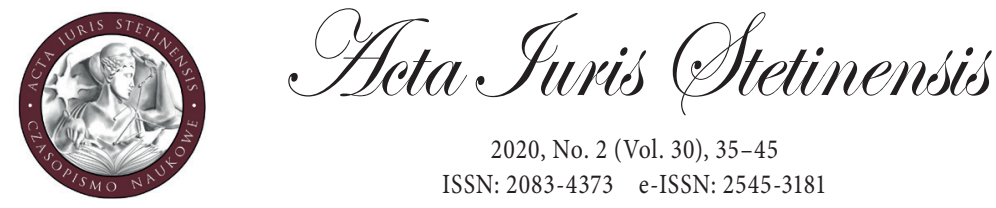

2020, No. 2 (Vol. 30), 35-45

ISSN: 2083-4373 e-ISSN: 2545-3181

DOI: $10.18276 /$ ais.2020.30-03

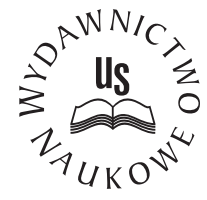

Agnieszka Kania-Chramęga

Ph.D.

University of Zielona Góra, Poland

e-mail: a.kania@wpa.uz.zgora.pl

ORCID ID: 0000-0001-6246-3172

\title{
Controversy regarding statutory circumstances that affect judicial sentencing either in a principally aggravating or mitigating manner. Reflections against the background of the regulation of Article $53 \$ 2$ of the Polish Criminal Code
}

\begin{abstract}
The purpose of this article is to determine whether the circumstances referred to in Article $53 \S 2$ of the Criminal Code, which affect the amount of the penalty, may be seen as clearly aggravating or mitigating circumstances by way of interpretation. The undertaken analyses were based on the recognition of the code essence circumstances, referring to: committing an offence to the detriment of a person due to their age or state of health, committing an offence together with a minor and circumstances exposing the value of compensation by the perpetrator for the damage or compensation by the perpetrator in another form to the social sense of justice. As resulted from the analysis - irrespective of the absence of a catalogue of mitigating and penalising circumstances - some of the factors specified in Article $53 \$ 2$ of the Criminal Code, in principle, have a clearly unidirectional character of impact, in fact affecting the mitigation or strengthening of the sanctions of criminal law applied. The analyses were based on the formal-dogmatic method.
\end{abstract}

Keywords: redressing the damage or satisfying the public sense of justice in any way, committing an offence to the detriment of a person due to their age or state of health, committing an offence together with a minor 


\section{Introduction to the issues at hand}

Statutory indications of judicial sentencing are of a markedly non-uniform nature. The process at issue is statutorily determined not only by general and particular directives and by the principles that shape the sentence, but also illustratively indicated circumstances, which - supplementing the tenets of general directives of sentencing - may directly influence the level of severity exacted upon the perpetrator. Even on the basis of these remarks, one may in fact imply that judicial sentencing is co-shaped by a number of factors which should be assessed with regard to their interconnectedness. As a result, one should then add that a particular criminal law response applied against the perpetrator should not constitute the result of the personal beliefs of the adjudicating court, or of the expectations of respective parties to the proceedings, ${ }^{1}$ but should be an outcome of statutory indications that determine its type and its extent. ${ }^{2}$

\section{Aggravating and mitigating nature of the circumstances resulting from Article $53 \$ 2$ of the Polish Criminal Code}

Due to the issues highlighted in the title, the following deliberations shall concentrate on select circumstances from Article $53 \$ 2$ of the Code that influence judicial sentencing. ${ }^{3}$ While approaching the essence of the codified solution at issue (i.e. Article $53 \S 2$ of the Code), one should at first stress ${ }^{4}$ that it exhibits, above all, a "supplementary" nature vis-à-vis the general directives of sentencing that flow from Article $53 \S 1$ of the Code. ${ }^{5}$ It is also worth noting that the regulation commented on refers to the most typical and, at the same time, repeatable factors, which - as stressed in academia - "manifest almost in their entirety in all criminal cases". At the same time, it must be said here that there is no expressis

1 Gubiński, A., Dyrektywy wymiaru kary, “Zagadnienia Wykroczeń” 1978, No. 4-5, pp. 21-30, p. 29, cf. also Judgment of the Appellate Court in Szczecin of 21 December 2006, II AKa 168/06, LEX No. 283405.

2 Judgment of the Appellate Court in Warszawa of 8 June 2016, II AKa 75/16, Legalis No. 1564414.

3 As to its scope, an amendment effected on the basis of the amending act of 23 March 2017 shall be taken into account, Dz.U. (Journal of Laws) 2017, item. 773.

4 Cf. Maksymowicz, K. and Szewioła, T., Okoliczności obciążające w ujęciu teorii i orzecznictwa Sądu Najwyższego, "Nowe Prawo" 1982, No. 3-4, pp. 52-66.

5 Marek, A., Kodeks karny. Komentarz, Warszawa 2007, p. 143.

6 Konarska-Wrzosek, V., in: Stefański, R.A. (ed.), Kodeks karny. Komentarz, Warszawa 2017, pp. 421-422. 
verbis typology of the circumstances referred to that would allow us - per the example of the Code of Contraventions - to distinguish a separate list of aggravating and mitigating circumstances. Omission of the chapter thus mentioned, true to the tradition of former criminal codifications, ${ }^{7}$ was caused - as one might surmise - not only by trust in judicial faculties, ${ }^{8}$ but also by the conviction that it would be impossible - barring certain exceptions - to consider a given circumstance a priori as unconditionally aggravating or mitigating. ${ }^{9}$ In turn, the absence of an exhaustive list of these circumstances constituted, without any reasonable doubt, a consequence of factual impossibility and substantive inaccuracy of containing them in a catalogue that would be "numerus clausus". ${ }^{10}$ The phrase "above all", used in the wording of the act, unequivocally evidences the fact that the court may also take account of other extraneous factors that would remain complementary to the normatively indicated set of factors. ${ }^{11}$ As such, an extraneous circumstance that is markedly mitigating in its nature is said to be found in e.g. a guilty plea, ${ }^{12}$ repentance or apology to the

7 "The Bill does not contain the so-called catalogue of aggravating and mitigating circumstances, a catalogue that is normally non-exhaustive (illustrative), drawn up for the convenience of the court. Such a catalogue, as it is known, is contained only by a few criminal codes of socialist states (...). Omitting a catalogue of aggravating and mitigating circumstances also follows from another premise. Such a catalogue very strongly accentuates "balancing" a sentence as a retribution. While the Bill does not negate this nature of a sentence, it strives to modify the idea of retribution with teleological considerations, pointing to other directives in regard to sentencing" - Projekt kodeksu karnego oraz przepisów wprowadzajacych, Warszawa 1968, p. 113. It must, however, be posited that the bill of 1963 nonetheless foresaw, under Articles 59 and 60, respectively, a catalogue of aggravating and mitigating circumstances for the purposes of sentencing.

8 The reason given for abandoning the creation of a catalogue of mitigating and aggravating circumstances was also the need to take greater account of the purposefulness of a sentence in the process of meting out thereof. Andejew, I. et al., Kodeks karny z komentarzem, Warszawa 1973, p. 230.

9 Wolter, W., Zasady wymiaru kary w kodeksie karnym z 1969 r., "Państwo i Prawo" 1969, No. 10, pp. 515-516.

10 Ibidem, p. 515.

11 Bafia, J. et al., Kodeks karny. Komentarz. Warszawa 1977, p. 176.

12 "The Appellate Court considers a guilty plea as the most important factor - second only to genuine remorse (lit. "active remorse", "czynny żal") and forgiveness on part of the victim - a circumstance mitigating the sentence. A guilty plea causes the objectives of criminal proceedings be met even before making a judgment on the issue, for when the defendant enters a guilty plea, he or she has already condemned him- or -herself and repented his or her actions, which is a symptom of striving to better oneself, which is one of the preventive objectives of proceedings". It might be added that the nature of a mitigating circumstance was accorded to the "abruptness of intent" that governed the perpetrator's actions" - Judgment of the Appellate Court in Kraków of 17 September 2008, II AKa 119/08, Legalis No. 130563; cf. also Judgment of the Appellate Court in Wrocław of 7 November 2019, II AKa 317/19, LEX No. 2761629. 
aggrieved, ${ }^{13}$ whereas repetitive commission of a certain type of act prohibited by punishment is said to be an aggravating circumstance. ${ }^{14}$

It therefore follows from the findings above that circumstances indicated under Article $53 \S 2$ of the Code have not been exhaustively listed thereunder and that they have - in genere ${ }^{15}$ - a neutral tenor, which would imply that, only in concreto, they may function to the advantage or to the detriment of the perpetrator.

Irrespective of the verity of the above statement, it should be indicated here that - in particular - the results of a teleological interpretation may corroborate a finding that some of the circumstances referred to under the provision commented on would directly affect the perpetrator to his detriment. Keeping in mind the intention of the drafters of the bill, such a nature applies to the circumstance of committing an offence to the detriment of a person who is helpless due to age or their health, recently introduced under Article $53 \$ 2$ of the Code. It is worth noting that the statutory wording of the indicated circumstance was subjected to certain modifications at the stage of drafting the bill. ${ }^{16}$ In its original version, it was supposed to express the need of a de facto more severe punishment of perpetrators as to crimes committed "to the detriment of a minor". As advocated in the statement of reasons for the amending bill: "The introduction of an additional circumstance to the directives of sentencing would cause the courts to be obliged, in all criminal cases, to check whether the crime was not committed to the detriment of a minor.

13 It is also added thereto that: “(...) an apology made only for the sake of appearances may not be found to be an aggravating circumstance" - Judgment of the Appellate Court in Kraków of 25 September 2012, II Aka 133/12, Legalis No. 589080; Judgment of the Appellate Court in Kraków of 17 May 2000, II AKa 74/00, Legalis No. 70523; Judgment of the Appellate Court in Lublin of 30 August 2016, II AKa 190/16, Legalis No. 1509174.

14 Cf. in that regard: Judgment of the Appellate Court in Lublin of 16 February 2010, II AKa 7/10, Legalis No. 284938.

15 Giezek, J., in: Giezek, J. (ed.), Kodeks karny. Część ogólna. Komentarz. Warszawa 2007, p. 404. On the other hand, one should take into account the position of the Supreme Court of the Republic of Poland, which opined that "the aggravating circumstance is found in the co-commission of a crime by a perpetrator who came of 17 years of age, with a minor, yet the importance of that circumstance wanes if the difference in ages between that perpetrator and the minor was insignificant" - Judgment of the Supreme Court of 27 August 1980, V KRN 189/80, OSNKW 1980, No. 10-11, item. 81.

16 Uzasadnienie przedstawionego przez Prezydenta Rzeczypospolitej Polskiej projektu ustawy o zmianie ustawy - Kodeks karny oraz ustawy o postępowaniu w sprawach nieletnich, Sejm Paper No. 846, pp. 4-5, http://www.sejm.gov.pl/sejm8.nsf/druk.xsp?nr=846 (accessed 5.09.2020); cf. Kania, A., Popetnienie przestępstwa na szkodę osoby nieporadnej ze względu na wiek lub stan zdrowia jako okoliczność wplywająca na wymiar kary. Rozważania na tle regulacji art. $53 \$ 2$ k.k., in: Paluszkiewicz, H. (ed.), Zmiany w prawie karnym materialnym i procesowym w latach 2013-2017. Zagadnienia wybrane, Zielona Góra 2019, p. $21 \mathrm{ff}$. 
In the event of a finding that it was indeed so, the court would have to mete out a more severe sentence in comparison to an analogous crime, but not committed to the detriment of a minor. The amendment of Article $53 \$ 2$ of the Code results in a bill that offers comprehensive protection of the rights and interests of minors. That protection is offered not only through provisions under which the statutory condition of being a minor was introduced, but also through the duty to take into account the rights and interests of a minor in each and every criminal case". ${ }^{17}$ This statement was compatible with other solutions of that very bill, with which it was hoped to bolster the level of protection offered for minors. ${ }^{18}$ Such a guarantee was, in particular, envisaged in the exacerbation of the statutory sentencing thresholds in the event of committing crimes to the detriment of the indicated category of aggrieved parties.

However, having in mind the final wording of the provision commented upon, one would have to concede that the circumstance relevant for sentencing turns out to be the commission of an offence not only to the detriment of a minor, but also to the detriment of an adult person whose age or state of health should de facto incline anyone to offer help or show care, rather than engage in illegal exploitation of their helplessness. The adopted version of the regulation commented upon, while undoubtedly more rational, does not, however, dispel a number of doubts in its interpretation. One plainly cannot deny, exempli gratia, a position expressed in the academia that the amended wording of Article $53 \$ 2$ of the Code displays certain deficiencies even from a purely linguistic point of view. ${ }^{19}$ It follows from the wording of the provision at issue that "where the court metes out a sentence, it shall, above all, take account of the motivation and the manner in which the perpetrator behaved, in particular where the offence was committed to the detriment of a person helpless due to age or the state of their health (...)", which in turn would imply that taking account of the motivation and the manner in which the perpetrator behaved refers - especially - to a situation where an offence was committed to the

17 Uzasadnienie ..., op. cit.

18 As advocated in the statement of reasons for the bill at issue: "Minor persons are highly susceptible to exploitation by other persons, with said persons having the objective of direct or indirect restriction of the personhood and autonomy of minors. Infringement of the rights and interests of a minor exhibits very large social harmfulness assessed in abstracto. A child finds it much more difficult to defend him- or herself, and harm inflicted on him or her affect his or her development and the entirety of his or her future life very negatively" - Uzasadnienie ..., op. cit.

19 Romańczuk-Grącka, M., Osoba nieporadna jako przedmiot czynności wykonawczej po nowelizacji z 23 marca 2017 r., in: Cieślak, W. and Romańczuk-Grącka, M. (eds.), Między stabilnościq a zmiennościa prawa karnego. Dylematy ustawodawcy, Olsztyn 2017, p. 499. 
detriment of a person helpless due to age or the state of their health. Against this background, a controversy emerges - is this kind of preponderance, mandating the court to take account of the circumstance at issue "in particular" in the event of committing an offence to the detriment of a person helpless due to age or the state of their health, substantially accurate and genuinely intended by the legislator? ${ }^{20}$

The demonstration of dependencies between the motivation and the manner of behaviour of the perpetrator and the offence committed to the detriment of a person helpless due to age or the state of their health, emphasised in the abovementioned statutory formula, is equally problematic. ${ }^{21}$ Recognising in this respect some de facto inevitable difficulties of interpretation in literature, it is argued that it would be much less controversial (which, however, would not diminish any other objections raised to the commented amendment) to just establish that the crime was committed to the detriment of a helpless person rather than proving: "(...) beyond any doubt that the perpetrator was aware of it, and its intention encompasses the age or state of health, or in the most general sense, helplessness of the aggrieved party". ${ }^{22}$

Some doubts also arise as to the issue of the understanding of the notion of a helpless person, ${ }^{23}$ as well as in an attempt to concretise the essence of a "crime committed to the detriment" of a person who is helpless due to their age or state of health. In the context of the latter wording, it seems that the indicated factor is taken into account both in the situation where the helpless person has suffered damage to any legal interests, both of a non-pecuniary (e.g. health, freedom, honour) or pecuniary nature.

However, it would be more disputable to determine whether the damage may be of both a direct and indirect nature, for example related to the mental trauma suffered in cases where the helpless person specified in Article $53 \$ 2$ of the Criminal Code is a witness to a crime committed by the perpetrator. ${ }^{24}$ Therefore, in light of the given example, the position assuming that the phrase "to the detriment of a helpless person" should be viewed from the perspective of treating a helpless per-

\footnotetext{
20 Ibidem.

21 Ibidem.

22 Ibidem.

23 Hałas, R., in: Grześkowiak, A. and Wiak, K. (eds.), Kodeks karny. Komentarz, Warszawa 2018, p. 470 ff.; Konarska-Wrzosek, V., in: Konarska-Wrzosek, V. (ed.), Kodeks karny. Komentarz. Warszawa 2016, p. 904; Hofmański, P. et al., in: Hofmański, P. (ed.), Kodeks postępowania karnego. Tom I. Komentarz do art. 1-296, Warszawa 2011, p. 394.

24 Kłączyńska, N., in: Giezek, J. (ed.), Kodeks karny. Czessć ogólna. Komentarz, Warszawa 2007, p. 368.
} 
son as a victim of a given crime is much more convincing. ${ }^{25}$ The proposed course of interpretation would require demonstrating that there is a direct link between the crime committed and the violation or threat to the legal right of the person referred to in Article $53 \$ 2$ of the Criminal Code. ${ }^{26}$

Furthermore, one could also consider whether the discussed solution, in its current wording, will in fact turn out to be a "determinant" for strengthening of the punishment as assumed by project promoters. It seems that such an automatisation would actually hurt in its absurdity, especially if, for example, the age difference between the victim and the perpetrator is negligible. ${ }^{27}$

Challenging the accuracy of the amendment, it is worth noting once again that the list of circumstances set out in Article $53 \S 2$ of the Criminal Code is of an open nature, which means that it may also be supplemented by other factors. It seems that apart from the common nature ${ }^{28}$ exposed in this respect by textbooks, the essence of the discussed category of factors would undoubtedly include an offence committed to the detriment of a helpless person due to their age or state of health. ${ }^{29}$

A category of circumstances which - in principle - affects the punishment in a one-way manner includes a crime committed "together with minors". The proper construction of the circumstance should not focus only on the indicated verba legis accessorial liability as far as meeting the definition of the crime is concerned, but

25 Golonka, A., Nowe oblicze walki z pedofilia w świetle nowelizacji Kodeksu karnego, "Palestra" 2008, No. 3-4, pp. 32-33; Melezini, M. and Sakowicz, A., Zakaz prowadzenia działalności związanej $z$ wychowaniem, leczeniem, edukacja lub $z$ opieka nad nimi jako nowy środek karny, "Archiwum Kryminologii" 2007-2008, No. XXIX-XXX, p. 575.

26 Siwek, M., Glosa do post. SN z 23.4.2002 r., I KZP 10/02, "Prokuratura i Prawo" 2004, No. 3, p. 113; Dudka, K., Skuteczność instrumentów ochrony praw pokrzywdzonego w postępowaniu przygotowawczym w świetle badań empirycznych, Lublin 2006, p. 20.

27 Judgment of the Supreme Court of 27 August 1980, op. cit.; cf. also Budyn-Kulik, M., in: Mozgawa, M. (ed.), Kodeks karny. Komentarz. Warszawa 2012, p. $145 \mathrm{ff}$.

28 Bafia, J. et al., op. cit., p. 176.

29 It is worth noting, however, that the open nature of the catalogue contained in Article 53(2) of the Criminal Code does not allow us to draw the conclusion that the same catalogue of circumstances affecting the assessment of the degree of social harmfulness of an act may be arbitrarily supplemented by the adjudicating authority. Prima facie, such a conclusion could arise from the fact that a number of circumstances set out in Article $53 \$ 2$ of the Criminal Code coincide with those which the court takes into account when determining the degree of social harmfulness of the act under Article $115 \$ 2$ of the Criminal Code. Cf. Judgment of the Supreme Court of 20 September 2002, WA 50/02, OSNKW 2003, No. 1-2, item 9, in which it was stated that: "Due to the inadmissibility of the expanded interpretation of Article $115 \$ 2$ of the Criminal Code, it should be assumed that the commonness of the crime is not to be classified as a determinant of the degree of social harmfulness of the act". 
should also include within its scope such crimes as: fencing or accessory. ${ }^{30}$ A negative assessment of the behaviour specified in the content of this premise results primarily from the fact that in its consequences, it adversely affects the proper development of the minor, especially as far as the process of shaping their system of values is concerned, acting as a de facto anti-educational event, and thus being a scandalous example for a young person. ${ }^{31}$ Regardless of the above observation, it seems that in the context of the discussed circumstances, its significance also decreases if the difference in age between the perpetrator and the minor turns out to be insignificant. ${ }^{32}$

The circumstance that emphasises the efforts made by the perpetrator "to remedy damage or to satisfy the social sense of justice in another manner" remains in a clear antinomy - at least prima facie - in relation to statutory circumstances substantially affecting the punishment. Although it is stressed in jurisprudence that: "Any action to remedy the damage or injury suffered as a result of the crime deserves positive evaluation, regardless of whether it results from the sincere regret of the perpetrator or the process strategy adopted by him, because each of them reduces the unfavourable effects of the crime committed" 33 . However, the accompanying motives of the perpetrator (sometimes very easily recognisable) are not without significance from the perspective of a more in-depth assessment of such a perpetrator's gesture.

30 As pointed out by V. Konarska-Wrzosek, narrowing the interpretation of this premise to the forms of accessory liability for the crime specified in the Criminal Code is not justified by both normative and teleological considerations. Cf. Konarska-Wrzosek, V., in Melezini, M. (ed.), System Prawa Karnego. Tom 6. Kary i inne środki reakcji prawnokarnej. System Prawa Karnego, Warszawa 2016, p. 760. It is worth mentioning that the analysis of instances of inciting a "juvenile" (adequate to the terminology contained in Article 49 of the Criminal Code of 1932) to commit a crime allowed Zakrzewski to distinguish the following types: 1) incitement sui generis, consisting in the multiple purchase of stolen goods from the juvenile (distinguishing this type of incitement, the author proposed to differentiate sui generis incitement from occasional fencing, stating that in the latter case, there is no element of prior acquaintanceship of a minor with an adult perpetrator, 2) classical incitement, including typical instances of incitement, for example to theft, 3) extended incitement, consisting in the fact that additional elements are added to classical incitement, which extend them to complicity and aiding, 4) involving the juvenile in the offence related to the engagement of a minor to assist in a crime committed by a criminal person - cf. Zakrzewski, P., Wspótdziałanie $w$ przestępstwie młodocianych i dorosłych z nieletnimi, Kraków 1960, pp. 107-112 and 135-138.

31 Resolution of the Supreme Court of 9 June 1976, VI KZP 13/75, OSNKW 1976, No. 7-8, item. 86. Cf. also Uzasadnienie ..., op. cit.

32 Judgment of the Supreme Court of 27 August 1980, op. cit.

33 Judgment of the Appellate Court in Kraków of 5 February 2008, II AKa 6/08, LEX No. 392917. 
It is not raised without reason that only the voluntary redress of the damage and the actual willingness to compensate for harm suffered may actually affect the punishment. ${ }^{34}$ Therefore, it would be difficult to consider attempts to remedy the damage, as a mitigating circumstance, and reconcile them with individual and general-prevention objectives in the situation where such attempts would result from the sole manifestation of a rational calculation of the perpetrator, a self-serving behaviour, rather than critical self-reflection on de facto reprehensible behaviour.

\section{Concluding remarks}

The above-presented arguments prove that the process of judicial punishment inevitably involves an element of evaluation, and therefore the need to carefully balance a number of circumstances integrally relating to the perpetrator, as well as the act committed by the perpetrator. As follows from the analysis of the provisions contained in the Criminal Code - irrespective of the absence of a catalogue of mitigating and penalising circumstances - some of the factors specified in Article $53 \$ 2$ of the Criminal Code, in principle, have a clearly unidirectional character of impact, in fact affecting the mitigation or strengthening of the sanctions of criminal law applied.

\section{References}

Andejew, I. et al., Kodeks karny z komentarzem, Warszawa 1973.

Bafia, J. et al., Kodeks karny. Komentarz, Warszawa 1977.

Budyn-Kulik, M., in: Mozgawa, M. (ed.), Kodeks karny. Komentarz, Warszawa 2012.

Dudka, K., Skuteczność instrumentów ochrony praw pokrzywdzonego w postępowaniu przygotowawczym w świetle badań empirycznych, Lublin 2006.

Giezek, J., in: Giezek, J. (ed.), Kodeks karny. Czessćc ogólna. Komentarz, Warszawa 2007

Golonka, A., Nowe oblicze walki z pedofilia w świetle nowelizacji Kodeksu karnego, "Palestra" 2008, No. 3-4.

Gubiński, A., Dyrektywy wymiaru kary, “Zagadnienia Wykroczeń” 1978, No. 4-5.

34 Judgment of the Appellate Court in Szczecin of 26 September 2013, II AKa 168/13, Legalis No. 744321; Judgment of the Appellate Court in Wrocław of 4 April 2013, II AKa 81/13, Legalis No. 999518; Judgment of the Appellate Court in Kraków of 11 October 2007, II AKa 191/07, Legalis No. 96359; Decision of the Supreme Court of January 16, 2007, V KK 390/06, Legalis No. 120987. 
Hałas, R., in: Grześkowiak, A. and Wiak, K. (eds.), Kodeks karny. Komentarz, Warszawa 2018.

Hofmański, P. et al., in: Hofmański, P. (ed.), Kodeks postępowania karnego. Tom I. Komentarz do art. 1-296, Warszawa 2011.

Kania, A., Popetnienie przestępstwa na szkodę osoby nieporadnej ze względu na wiek lub stan zdrowia jako okoliczność wpływająca na wymiar kary. Rozważania na tle regulacji art. 53\$2 k.k., in: Paluszkiewicz, H. (ed.), Zmiany w prawie karnym materialnym i procesowym w latach 2013-2017. Zagadnienia wybrane, Zielona Góra 2019.

Kłączyńska, N., in: Giezek, J. (ed.), Kodeks karny. Część ogólna. Komentarz, Warszawa 2007.

Konarska-Wrzosek, V., in: Konarska-Wrzosek, V. (ed.), Kodeks karny. Komentarz, Warszawa 2016.

Konarska-Wrzosek, V., in: Melezini, M. (ed.), System Prawa Karnego. Tom 6. Kary i inne środki reakcji prawnokarnej. System Prawa Karnego, Warszawa 2016.

Konarska-Wrzosek, V., in: Stefański, R.A. (ed.), Kodeks karny. Komentarz, Warszawa 2017.

Maksymowicz, K. and Szewioła, T., Okoliczności obciążające w ujęciu teorii i orzecznictwa Sądu Najwyższego, "Nowe Prawo" 1982, No. 3-4.

Marek, A., Kodeks karny Komentarz, Warszawa 2007.

Melezini, M. and Sakowicz, A., Zakaz prowadzenia działalności zwiąanej z wychowaniem, leczeniem, edukacja lub z opieka nad nimi jako nowy środek karny, "Archiwum Kryminologii” 2007-2008, No. XXIX-XXX.

Projekt kodeksu karnego oraz przepisów wprowadzających, Warszawa 1968.

Romańczuk-Grącka, M., Osoba nieporadna jako przedmiot czynności wykonawczej po nowelizacji z 23 marca 2017 r., in: Cieślak, W. and Romańczuk-Grącka, M. (eds.), Między stabilnością a zmiennością prawa karnego. Dylematy ustawodawcy, Olsztyn 2017.

Siwek, M., Glosa do post. SN z 23.4.2002 r., I KZP 10/02, "Prokuratura i Prawo" 2004, No. 3.

Uzasadnienie przedstawionego przez Prezydenta Rzeczypospolitej Polskiej projektu ustawy o zmianie ustawy - Kodeks karny oraz ustawy o postępowaniu w sprawach nieletnich, Sejm Paper No. 846, http://www.sejm.gov.pl/sejm8.nsf/druk.xsp?nr=846.

Wolter, W., Zasady wymiaru kary w kodeksie karnym z 1969 r., "Państwo i Prawo" 1969, No. 10.

Zakrzewski, $\mathrm{P}$, Współdziałanie $w$ przestępstwie młodocianych $i$ dorosłych $z$ nieletnimi. Kraków 1960. 


\section{CITATION}

Kania-Chramęga, A., Controversy regarding statutory circumstances that affect judicial sentencing either in a principally aggravating or mitigating manner. Reflections against the background of the regulation of Article $53 \$ 2$ of the Polish Criminal Code, "Acta Iuris Stetinensis" 2020, No. 2 (Vol. 30), 35-45, DOI: 10.18276/ais.2020.30-03. 